\title{
Teddy bears, Tamagotchis, transgenic mice: A semiotic typology of artificial animals
}

\author{
Dagmar Schmauks \\ Technical University Berlin, \\ Ernst-Reuter-Platz 7, D-10587 Berlin, Germany \\ e-mail: dagmar.schmauks@tu-berlin.de
}

\begin{abstract}
The expression "artificial animal" denotes a range of different objects from teddy bears to the results of genetic engineering. As a basis for further investigation, this article first of all presents the main interpretations and traces their systematic interconnections. The subsequent sections concentrate on artificial animals in the context of play. The development of material toys is fueled by robotics. It gives toys artificial sense organs, limbs, and cognitive abilities, thus enabling them to act in the real world. The second line of development, closely related to research into Artificial Life, creates virtual beings "living" on computer screens. The most essential difference between these variants are the sense modalities involved in interaction. Virtual beings can only be seen and heard, whereas material toys can be touched as well. Therefore, the simulation of haptic qualities plays an important role. In order to complete the proposed typology, two further areas are outlined, namely artificial animals outside play and "artificial animals in the medium of flesh" which are alive but designed and created by man. Research on artificial animals belongs to an extended notion of ecosemiotics, as they are part of ecosystems which may themselves be virtual such as the Internet.
\end{abstract}

\section{Introduction}

The expression "artificial animal" has several interpretations which can be classified by semiotic categories. Three sign functions are of special interest for ecosemiotics: artificial animals may represent liv- 
ing animals, substitute them in specific contexts, or be intended as an improvement of nature.

In the standard case, "artificial animal" means representations of living animals. Classical toys such as teddy bears are material and therefore three-dimensional models which can be perceived by all sense modalities. During the last few years, virtual (or digital) animals have been created which are two-dimensional representations on a computer screen. In contrast to traditional pictures, they can move and may have a voice. And in contrast to artificial animals in movies (like the Aristocats or Roger Rabbit), the player can interact with them.

The second interpretation suggests that animal representations are "artificial" only if they do not have a model in reality. Examples include the fabulous beasts of mythology and the monsters from outer space in science fiction. Hybrids of man and animal (e.g., sirens, centaurs, and sphinxes) and later on of living beings and machines (cyborgs) are typical here. They all exist initially only in the fantasy of their inventor and are introduced to common imagination by texts, pictures, films, or sculptures. The fact which is not investigated here is that many artificial animals can be interpreted as caricatures of human beings. Donald Duck and his relatives, for example, are not only ducks whose adventures please their readers, but also a model of the human condition in which all characters are stereotypes as in the commedia dell'arte.

The third interpretation of "artificial animal" is a living animal which has been "artificially" created by man. Under natural circumstances, only closely related species cross-breed spontaneously - for example, the mule is a cross-breed of horse and donkey. Genetic engineering, however, allows for cross-breeding of more distant species, even of plants and animals, or of animals and man. The result may be creatures which are "mixed" like fabulous beasts. The circle of development closes in the case of re-breeding which is intended to slow down the loss of biodiversity.

These three readings are systematically interconnected. Dealing with living animals encourages fantasies in which animals are "mentally divided" into their body parts which are then "freely composed" into fabulous beasts. Sometimes nature itself offers such impulses, namely by deformed children and animals. Through observation the features in question become "parametrized". If, e.g., calves with two heads or six legs are born, the number of heads and legs is no longer a constant factor. And vice versa: the "invention" of fabulous beasts 
may be one of the sources which has established genetic engineering as a scientific vision. Furthermore, fabulous beasts can become intersubjectively available as material or virtual toys. And handling them may influence behavior towards living animals. "Animal Makers", for example, who produce artificial animals for Hollywood, support organizations committed to the protection of animals on film sets.

Models of animals belong to the earliest remains of material culture, but whether they were toys, sacrifices or mere decoration is not always easy to decide. In ancient Egypt, for example, models of livestock were placed in tombs in order to guarantee the eternal alimentation of the deceased. Since then, man has created a variety of artificial animals, often by using the most advanced technology. Multifunctionality is frequent, for example, toys may be amulets at the same time.

The following sections offer a typology of artificial animals. The main emphasis is placed on artificial animals in the context of play, the development of which is characterized by the simulation of more and more live-functions (section 2). The history of material toys ranges from simple static models and clockwork toys to today's robotic toys which simulate locomotion, perception, sound utterances, and units of behavior ("Fetch the stick!"). The second line of development - related to research into Artificial Life - creates virtual animals such as Pokémons which "live" on computer screens. Their simulation consists of metabolism, growth, and social behavior (including reproduction), and even a quasi-genetic optimization to a specific environment may take place. Section 3 gives an impression of the manifold simulation of animals outside play which is another fruitful area for semiotic investigation. The same is true for artificial animals in the medium of flesh which is outlined in section 4 . The presentation is closed by a conclusion and an outlook analysis in section 5 .

\section{Artificial animals in the context of play}

In the context of play, more and more live functions are simulated. From a semiotic point of view, the most essential difference between material (2.1) and virtual (2.2) toy animals are the sense modalities involved in interaction. Virtual animals can only be seen and heard, whereas the material ones are often specifically intended to stimulate the skin. Therefore, the simulation of haptic qualities - such as temperature, softness, elasticity, and texture - plays an important role. 


\subsection{Material toy animals}

The history of toy animals can be traced from various viewpoints, for example, as a part of cultural history (cf., e.g., Fraser 1966 and Bryant-Mole 1996) or as a reflection of didactic concepts. The following investigation concentrates on toys which - at least roughly - imitate animals' appearance. "Natural toys" such as stones and cones are not considered here, although they can adopt the roles of animals during play. This section concentrates on two aspects which are relevant for a semiotic analysis, namely the simulation of live functions (2.1.1) and of haptic features (2.1.2).

Toy animals are frequently designed as the elements of complex scenarios. Paradise and Noah's ark are famous historic examples motivated by religious belief. Other scenarios depict the everyday life of pre-industrialized farming - often idealized by nostalgia, as in the case of farms with free-range animals (the fact that no toy sets simulating industrialized livestock breeding exist may be read as an indication that we feel ashamed in front of our children). Some further scenarios are already second-order models because concepts such as "zoo" and "circus" are themselves culture-specific models of nature and its relationship to man.

There are manifold ways in which toys are given a "serious" function and vice versa, for example, on the one hand, a teddy bear promotes the canned milk brand name "Bärenmarke", and on the other hand, the Berlin bear as a heraldic sign is sold as a soft toy. However, this is not treated in more detail here.

\subsubsection{The simulation of live functions}

In the beginning of history, all toy animals were static and silent. The first simulation of movement are toys for dragging and those with moving parts. Fraser (1966: 26 and 31) shows examples from around 1100 B.C., namely a lion on wheels and a crocodile with movable lower jaws. Also in the case of rocking horses (cf. Mullins 1992), it is the player himself who makes them move. Although singular automata such as singing birds or picking hens are known to have existed since Western and Chinese antiquity (cf. Fraser 1966: 108ff), the simulation of movement and voice remained an exception until the 
late 19th century. By means of clockworks and later on by batteries, moving toy animals started to be produced. Phonographs and later on acoustic chips gave them voices. In contrast to ancient rattles which only make noise (Fraser 1966: 49), modern devices allow for producing species-specific sound utterances like grunting or barking.

Today, a highly sophisticated simulation of live functions has become possible. One line of development is fueled by robotics. It gives toy animals ("toybots") artificial sense organs, artificial limbs, and cognitive abilities such as planning and reasoning, thereby enabling them to perceive their environment and to act in the real world. One long-term objective is the motor-driven robot-cat "Robokoneko" whose "brain" is to contain 40 million artificial neurons arranged in modules. Each neuronal net can be optimized by quasi-genetic processes for a specific task such as the recognition of "prey". The cat "sees" by video camera, "hears" by stereo microphones, and also the tactile hairs contain sensors. A sound generator allows for miaowing, purring, and other sound utterances.

Robot-dogs such as "Aibo" and "I-Cybies" are also already available. I-Cybies was presented in February 2000 at the Nuremberg toyfair in Germany. When activated, his speech recognizer adapts to his master's voice, and afterwards, he obeys only him. I-Cybies can bark, howl, roll, and follow simple orders like following his master, standing on his hind legs, and retrieving. During locomotion, he avoids hitting obstacles. He knows his name, and interaction with his environment results in specific "moods" which he expresses by "facial expression". For example, he droops his ears sadly if not sufficiently caressed. Another subsystem of mood expression, however, has no model in reality: if I-Cybies is happy, his otherwise green eyes glow red.

Whereas these toybots are intended to appeal to adults, "Furbies" are primarily designed for children. They look like normal soft toys, but contain enough computer technology to be treated as "partly animate" (cf. Pesce 2000). They interact with their environment, show their mood by facial expression and gaze behavior, and have a "language" evolving from a childlike patois ("Furbish") to a rudimentary English. 


\subsubsection{The simulation of haptic features}

The 20th century brought the rise of soft toys. At first, only furry mammals such as bears and cats were simulated (cf. Fraser 1966: 182f), later on also animals which are phylogenetically more distant from man, e.g., marine mammals, reptiles, and even spiders and other invertebrates.

From semiotically perspective it is interesting how the naturalness of simulation systematically varies due to the different features. The animal's general shape - the main criterion for identifying the species in question - is normally simulated to a comparably high degree. Some stylization may take place, for example the face may be modified to look more "human" or more "childlike". The color, however, is frequently changed completely. Pink lions and blue horses occur, maybe in order to please small children. If raised in an urban environment without contact with real livestock, children may acquire wrong beliefs about real animals' colors. A famous example is a longterm advertising campaign by Milka (Swiss chocolate) which makes children believe that cows are violet.

One special aspect is the simulation of haptic features. Real specimen have stunningly manifold "surfaces". Mammals' coats are curly or straight, silky or bristly, scanty or straggly. Birds have feathers, fishes and reptiles have scales of different types, turtles have shells, and snails have a slimy skin. In toy production, however, this variability may be reduced to only two extremes, namely the uniform fluffiness of toys for cuddling and the disgusting sliminess of creepycrawlies. The affective component may play a minor role in the case of toy collectors, but frequently, artificial toys trigger intense feelings. The numerous Halloween monsters are intended to provoke a reaction of fear or disgust.

Most toy animals, however, are intended for being loved as individuals, and a soft toy acquired in childhood may really become a "lifetime companion" (there are even guides about how to treat them well, cf. Ricketts 1969). Their sign function may change depending on their owner's age. For younger children, toy animals can substitute living animals to a high degree — they lovingly feed, brush and hug their toy cat. Older children intentionally switch between treating toy animals as living or as mere artifacts. For adults, toy animals may be signs of craftsmanship, of their donator's love, or lucky charms. 
With regard to this long-term usage and emotional impact, leading toy manufacturers such as "Steiff" or "Kösel" aim to produce highly naturalistic toy animals which carefully imitate their models' visual features - including color — and the haptic features of their skin. This may require the use of costly hand-woven furs the uneven texture of which looks and feels realistic.

The interior of objects, and especially of living beings, is normally not visible in reality. This normal opacity of flesh contributes to the fascination of transparent animals like jellyfishes and some geckos. Only in the case of severe injuries does the interior of living beings become accessible for visual and haptic exploration. But open fractures and the opening of cavities are traumatic for the affected as well as for the observer. Physicians, however, need this kind of "insight", and also modern diagnosis from X-ray to computer tomography cannot substitute for the visual-haptic knowledge acquired during autopsy.

If the interior of toy animals is accessible, these animals often have an educational objective. Since the 1980's, soft toys with babies in their womb allow for the simulation of birth. The detailed "anatomy teddy" allows children to literally "grasp" the location and shape of inner organs. Furthermore, this teddy is aimed at decreasing the fear of doctors and surgery due to its ability to completely "recover" (whereas unintended examinations of a normal teddy's interior tend to cause its destruction).

\subsection{Virtual toy animals}

The second line of the development of toy animals is closely related to Artificial Life, a branch of science which is located between biology and computer science (cf., e.g., Magnenat-Thalmann and Thalmann 1994 as well as Hokkanen 1999). Virtual — or digital — beings are computer-generated animation which are visible on the screen, move, and may have a voice.

Virtual fishes living in a virtual marine world are a scientific example (cf. Tu 1996). The simulation of individuals exhibits a complex repertoire of behavior, for example, avoiding obstacles, searching for food, and fleeing from predators. The underlying "intention generator" is based on a hierarchy of behavior in which the most basic desires have the highest priority. For example, the desire to eat or to mate can 
only occur if there is no danger of hitting an obstacle or being killed. If life-cycles are simulated as well, the individuals are born, grow, and die. In order to gain such complexity, the basic physics of the animals and their environment has to be modeled.

With groups of animals, social behavior including mating and breeding may be simulated, and even a quasi-genetic adaptation to a specific environment may take place. Research in this area sometimes uses a special terminology, calling living beings (including humans) "animals" and virtual beings "animats" (cf. Pfeifer 1998, as well as the previous Proceedings of the Conferences on Simulation of Adaptive Behavior). With regard to this typology, virtual animals are a special case of animats which also comprise virtual humans (which may be "avatars": virtual counterparts of Internet users) and all sorts of hybrids and fictional beings. If virtual beings "live" in the Internet - as a virtual ecosystem - and come into contact with many users, a virtual coevolution may take place during which each species refines its capabilities (cf. Funes et al. 1998).

From the viewpoint of computer science, creating virtual animals can fertilize the evolution of interactive adaptive software. For ethology, on the other hand, carefully designed artificial animals are useful tools for systematic studies of animal behavior (cf. Tu 1996). As they are structural as well as functional models, all levels from sensomotorics to cognition can be studied and modified without animal experiments. Furthermore, investigations of genetic adaptation profit from the fact that life-cycles of virtual animals may be extremely short. This research belongs to an extended notion of ecosemiotics because virtual worlds may be counted as ecosystems as well. The Internet, for example, can be seen as a virtual ecosystem, namely a community of human users and virtual beings where complex interaction is taking place (cf. Funes et al. 1998, chapter 1).

Commercially sold virtual animals exploit all these scientific results. In 1997, the "Tamagotchis" came from Japan to Europe. These "virtual chickens" live on the display of egg-sized "worlds" and need to be fed, nursed, and entertained by pressing buttons. They actively ask for attention by cheeping, but unnecessary cheeping has to be "punished". Their life span is restricted to 30 days, and neglect makes them die much earlier. They can be revived by the RESET-function (which raises the existential question of personal identity...) or be buried in specific Internet cemeteries. Furthermore, their producers as- 
sume that after death they return to their home planet - a philosophy which intermingles real and virtual world.

Two years later the "Pokémons" succeeded to the throne (and are already being replaced by the "Digimons"). Each Pokémon belongs to a species with specific powers such as fire, electro, or psycho. Meanwhile, some hundred Pokémons now exist, each of which has to be caught by skill and perseverance. Only by optimal training can a Pokémon develop in a species-specific manner. The aim of the training is to own a whole army of Pokémons to fight against others. This example shows that virtual animals require more and more involvement from the side of the user. A teddy bear may be forgotten for weeks without any damage — the optimal development of a Pokémon, however, requires extensive care over a considerable amount of time.

In contrast to Tamagotchis, Pokémons are part of a whole (commercial...) universe comprising also films and figures. As soon as virtual animals get material counterparts, the borders between the two realms are blurred. Furthermore, such animal figures are frequently introduced into new contexts. As a typical example, animals which have originally been produced for films may be sold later. Depending on the intentions of its new owner, a sculpture of Mickey Mouse can be used as a toy, exhibited as a piece of art, or become a coat stand.

In the Internet, catchwords such as "cyberlife", "virtualkitty", or "swineonline" lead to numerous virtual species which can be acquired. Many of them are only intended for playing and nursing, but virtual variants of hunting also exist. Virtual fishing rods are operated by real hand movements and allow for the choice between different bodies of water, baits, and times of the day. But the seamless integration of real and virtual world fails because the rod can't be exposed to humidity - the manual explicitly prohibits its use at riversides...

\section{Artificial animals outside play}

Numerous simulations of animals also exist outside play. The aim of this section is to list some suggestive examples in order to stimulate more detailed semiotic analyses.

Many artificial animals outside play have decorative function. One has to distinguish between variants which are designed as mere decorations (knick-knacks, jewelry, ...) and those which have a practical 
purpose as well (piggy banks, weathercocks, butcher's figurines of cows and pigs, ...).

In didactic contexts, there is no clear-cut difference between specimen and model - frequently, a real coat is put on a model made of gypsum ("dermoplastics"). This intermingling of model and representation is quite rare in the case of toys - stuffed chickens and ducklings which are sold around Easter on Austrian markets are a strange exception.

Animal models in bionics is a highly complex simulation by which the principles of living beings are investigated for translation into technical devices. The solutions of evolution - tested for millions of years - are studied with respect to the question whether they can be emulated by using non-organic materials.

Another special case are artificial animals used for camouflage such as the Trojan Horse in which a group of enemy soldiers hid. A life-size iron ox for torturing was created by the artist Perillus for Phalaris, the ruler of Agrigent. The convicted were roasted to death in the oxen's hollow body, and specific sound pipes transformed their cries so that they resembled the bellowing of an ox. A Greek legend (cf. Ranke-Graves 1960, I: 265f) tells of a camouflage due to transspecies love. Minos, the king of Crete, kept a wonderful bull which belonged to Poseidon. Poseidon cursed Pasiphaë, Minos' wife, to fall into love with this bull. She requested Daedalus to build a hollow wooden cow, covered by cow's hide (cf. some murals in Pompeji, Reinach 1922: 183). Hidden in the cow, Pasiphaë seduced the bull. The result of this mating is the Minotaure (with the head of a bull on the body of a man) for whom Daedalus later on built the famous labyrinth.

As in the case of toy animals, the simulation may comprise more or less features of the living animal. The high-tech security system called "Power Dog", for example, is a purely acoustic simulation which reduces a dog to its voice. The "digital barking" - which the manual describes as "truly natural" - is triggered by a motion sensor and is to make burglars believe that a huge dog is guarding the house.

Much more complex simulations are used in livestock breeding. Today, the artificial insemination of working animals is a standard procedure. However, it is only efficient if the sexual behavior of the species in question is taken into account. From foreplay to intercourse, it can be reconstructed as a chain of reflexes which coordinate the behavior of two individuals. If there is no contact between male and fe- 
male, the elements of the natural situation have to be simulated by different means (cf. Busch, Löhle und Peter 1991; semiotic reconstruction in Schmauks 2000). During semen collection, the female animal is normally replaced by a so-called "phantom", i.e., a dummy. It depends on the species in question to which extent phantoms must be true to nature. The minimal variant only has the structure of an archway, i.e., resembles a female's backside. Cow phantoms may be much more elaborate, simulating a cow's body with respect to size, volume, and color in order to offer distal visual stimuli. Its covering by cow hide additionally renders olfactory and tactile stimuli. The most relevant part is the artificial vagina which may be built into the phantom or handled separately by the veterinarian. Filling the doublewalled vagina with warm water simulates body temperature, and the pressure at the opening can be adapted to the liking of individual bulls. Vaseline simulates the tactile experience of the mucous membrane which triggers the immissio-penis reflex.

\section{Artificial animals in the medium of flesh}

Finally, in order to complete the proposed typology of artificial animals, it is important to ask to which extent the expressions "artificial" and "organic" still denote opposites, or, in other words: to which extent the artificial already exists in the medium of flesh.

Since the beginning of domestication in the Neolithic period, one aim of breeding has been the targeted modification of the animals' features. The selection of such desirable features always depends on circumstances: whereas in war times robust pigs delivering much bacon may be desired, in times of abundance lean pigs with additional chops are preferred. This development is "artificial" because it serves human goals, and it causes the loss of the "natural", namely of biodiversity.

Many cultures have mythical beings which are mixtures of different species. In ancient Greece, "chimaera" was at first the proper name of a creature with three heads: that of a lion, a goat, and a snake. Later on, the derived common noun "chimera" denoted all "mixed" beings. In some of them, one species dominates, e.g., the horse in the unicorn. Other examples - like sirens, sphinxes, centaurs, basilisks, and harpies - are more balanced mixtures. The transportation of such mythi- 
cal beings into reality has always been a fascinating aim, the achievement of which gives their creator a feeling of god-like power.

A step towards real cross-breeding is the "incarnation" of fabulous beasts made from dead specimens. One example from Bavaria, called "Wolpertinger", is created in order to deceive tourists. In the standard case, it has the body of a marmot, roebuck's antlers, and duck's feet. This is a very practical interpretation of the postmodern term "bricolage".

Several branches of today's biology create living chimeras. Plants which are closely related can be "mixed" non-sexually by grafting. Useful plants and domestic animals are frequently cross-bred in order to ameliorate one species or to combine desirable features of two species ("hybrids"). Hybrids for usage may be sterile like the mule.

Genetic engineering even allows for cross-breeds which are impossible in nature. Genes of another species are introduced into the DNA of such "transgenic" animals in order to reach specific goals, for example in human medicine. Transgenic mice are susceptible to human diseases such as arteriosclerosis, cancer, or AIDS, thus allowing for the testing of new therapies. A highly controversial subject for discussion is the use of genetic engineering in art - such as the albinorabbits of Eduardo Kac which fluoresce in the dark due to insertion of a gene of the jellyfish (Schmundt 2000).

In Ovid's Metamorphoses (1992), some humans — such as Narcissus, Hyacinthus, and Myrrh - are transformed into plants which then carry their names. Even such mixing of plants and animals has become possible by genetic engineering. A specific gene of the winter flounder prevents the water in the cells from freezing. By introducing this gene into tobacco plants, the latter become frost-resistant.

Unicorns and other fabulous beasts of the Ancient World - which have become a part of general world knowledge by textual and pictorial representations - surely have inspired cross-breeding as a scientific vision. On the other hand, the confrontation with deformed children and animals may have inspired the invention of fabulous beasts - this was Rudolf Virchow's basic premise when establishing the "Medical Collection" of the Charite in Berlin. By presenting a "second-order chimera" of four mythical beasts, Petermann and Schmauks (1999) aim at breaching the gap between mythology and genetic engineering from the other side. The result of this virtual cross-breeding is called "Sphingahornix cyclopica" — with the body 
of a sphinx and a mermaid's tail, one-eyed like a cyclops and onehorned like a unicorn.

A special case of "artificial" cross-breeding is re-breeding - the attempt to regain species which are already extinct in reality. Commercially oriented livestock breeding concentrates on desirable features, thus always resulting in an irretrievable genetic loss. In intensive livestock breeding, it is irrelevant whether animals are good mothers, get by on very little food, or can cope with rough weather. The most important aspect is that they are ready for slaughtering as soon as possible and render lean meat matching the clients' liking.

Alarmed by the dramatic shrinking of biodiversity, appreciation of old species of domestic animals has grown since the 1980's. Because some of them were already extinct, a targeted re-breeding was started. But an extinct species can never be regained in a strict sense. It is only possible to breed the descendants and wildlife forms for recombining remaining genes. The result are animals whose appearance and behavior resembles the original species as closely as possible. One example is the re-breeding of pigs: In 1980, Berlin's Free University started the breeding of wild boars, Hungarian Mangalitzas, and other land races for re-breeding the robust and undemanding "Düppeler Weideschwein" which is especially suited for extensive farming (cf. Hörning 1997: 56ff).

Saving endangered species can be attempted by genetic engineering as well. Fertilized eggs of the species in question can be cloned and then carried to term by surrogate mothers of closely related species. The "production" of embryos by fusing (arbitrary) cells of the endangered species and eggs without nuclei from other species is even more costly. Although such re-breeding cannot stop the general loss of genetic variability, it can at least reduce its negative results.

Depending on the advocated world view, all these artificial animals (or the intention to create them) are read as signs of human creativity, power, or hybris. For some theistic religions, e.g., the attempt to "be like God" is the ultimate sin, leading to eternal damnation.

\section{Conclusions and outlook}

The typology proposed here calls for a deepened semiotic investigation of the variants which have been distinguished. But already this sketchy presentation shows the variability of artificial animals which 
can be ordered according to "naturalness". At one pole, minimal models are located which only simulate a singular feature - like "Power dog", reducing a dog to its barking (cf. section 3). At the opposite pole, the model's aim is to simulate more and more features. Here, sophisticated animats are located which are not only naturalistic models of individuals, but also form virtual societies and live in an environment modeling the laws of physics.

Projecting current trends results in manifold visions, each of them based on different notions of "reality", "nature", and "mankind". From a humanistic viewpoint, intense contact to animals is always suspicious - as a waste of time, as a sign of misanthropy, or as a kind of perversion ("social sodomy"). This objection is intensified with regard to artificial animals. Other thought experiments not only welcome robot pets as new attractive toys but also enthusiastically introduce them to other tasks. Examples include geriatric nursing where they will be - like their living models — the last social contact of aged people.

Furthermore, artificial animals - which can be "neglected" or even "killed" without irreversible results — are suspected to cause an alineated attitude towards living beings. The essential didactic goal of keeping pets, namely the sensibilization for life's fragility, obviously cannot be reached in the realm of the virtual.

As soon as artificial animals become complex enough, we have to face the ethical question of how to treat them correctly. Such discussions will become more important the more we are convinced that they have "feelings" and even some "intelligence" (one can also argue that artificial beings - like other cultural assets — should be protected, even if their higher mental functions are not proven).

It has to be added that the ethical treatment of artificial beings should be in appropriate relation to our treatment of living beings. For example, it can be interpreted as a clear indication for our alineated attitude towards nature, if we have scruples about hitting a Furby, but accept the conditions of industrialized livestock breeding in which millions of animals undoubtedly feel pain and are kept far away from natural conditions. ${ }^{1}$

Acknowledgements. Thanks are due to Kalevi Kull and Roland Posner for helpful comments on the previous version of this paper. 


\section{References}

Asimov, Isaac 1956. The Caves of Steel. London: Science Fiction Book Club. (German: Der Mann von drüben. München: Heyne 1978.)

Bryant-Mole, Karen 1996. Toys Discovered Through History. London: A \& C Black.

Busch, Walter; Löhle, Klaus; Peter, Winfried (eds.) 1991. Künstliche Besamung bei Nutztieren. Jena and Stuttgart: Fischer.

Fraser, Antonia 1966. A History of Toys. London: Weidenfeld \& Nicolson. (German: Spielzeug. Die Geschichte des Spielzeugs in aller Welt. Oldenburg: Stalling 1966.)

Funes, Pablo; Sklar, Elizabeth; Juillé, Hugues; Pollack, Jordan 1998: AnimalAnimat Coevolution: Using the Animal Population as Fitness Function. In: Pfeifer, Rolf (ed.), From Animals to Animats 5: Proceedings of the Fifth International Conference on Simulation of Adaptive Behavior. Cambridge MA: The MIT Press, 525-533.

Hörning, Bernhard 1997. Gefährdete Schweinerassen und Alternative Schweinezüchtung. Wetzlar: NZH Verlag.

Hokkanen, Jyrki E. I. 1999. Visual Simulations, Artificial Animals and Virtual Ecosystems. The Journal of Experimental Biology 202 (23): 34773484.

Magnenat-Thalmann, Nadia; Thalmann, Daniel (eds.) 1994. Artificial Life and Virtual Reality. Chichester: Wiley.

Mullins, Patricia 1992. The Rocking Horse: A History of Moving Toy Horses. London: New Cavendish Books.

Ovid (Publius Ovidius Naso) 1992. Metamorphoses/Metamorphosen. Lateinisch-deutsch. Translated and edited by E. Rösch. 13th edition. München: Artemis and Winkler.

Pesce, Mark 2000. Toy Stories. The Sciences (September/October): 25-31.

Petermann, Christine and Schmauks, Dagmar 1999. Tomatoffel und die Folgen. Zeitschrift für Semiotik 21: 411.

Pfeifer, Rolf (ed.) 1998. From Animals to Animats 5: Proceedings of the Fifth International Conference on Simulation of Adaptive Behavior. Cambridge MA: The MIT Press.

Ranke-Graves, Robert von 1960. Griechische Mythologie. Quellen und Deutung. 2 volumes. Reinbek: Rowohlt.

Reinach, Salomon 1922. Répertoire des peintures Greques et Romaines. Paris: Leroux.

Ricketts, Viva Leone 1969. All About Toy Dogs: Their Care in Sickness and Health, Feeding, Training, Breeding and the History and Character of Each Breed. London: Hale. 


\section{Dagmar Schmauks}

Rötzer, Florian 2000. Künstliche Lebewesen. In: Deutsches Hygiene-Museum (ed.), Gehirn und Denken. Kosmos im Kopf. Ostfildern-Ruit: Hatje Cantz Verlag, 96-104.

Schmauks, Dagmar 2000. Phantome, Prothesen, Servonen. Die Simulation von Körperteilen und -funktionen in sexuellen Szenarien. To appear in: Proceedings of the 9th International Congress of the DGS (Dresden 1999).

Schmundt, Hilmar 2000. Das Kunst-Gen. Der Spiegel 26/2000: 114.

Tu, Xiaoyuan 1996. Artificial Animals for Computer Animation: Biomechanics, Locomotion, Perception, and Behavior. Department of Computer Science, University of Toronto: Dissertation.

\section{Плюшевые медведи, тамагучи, трансгенные мыши: семиотическая типология искусственных животных}

Выражение "искусственное животное" обозначает очень разные объекты от плюшевых медведей до результатов генной инженерии. В качестве основы дальнейшего исследования в статье прежде всего даются основные интерпретации и прослеживаются их систематические взаимосвязи. Последуюшие разделы посвящены искусственным животным в контексте игры. Развитие материальных игрушек обеспечивается роботроникой. Она снабжает игрушпи искусственными органами чувств, конечностями и когнитивными способностями, позволяя им действовать в реальном мире. Другая линия развития, тесно связанная с исследованием Искусственной Жизни, создает виртуальные существа, "живущие" на экране компьютера. Эти два варианта различаются прежде всего модальностями восприятия, которые включаются во взаимодействие: виртуальные сушества можно видеть и слышать, тогда как материальные игрушки можно и потрогать. Поэтому симуляция чувствительности (haptic qualities) играет важную роль. Для полноты предлагаемой типологии дается набросок двух следуюших областей исследования: искусственные животные вне игры и “искусственные животные во плоти", живые, но проектируемые и созданные человеком. Изучение искусственных животных принадлежит к экосемиотике в широком смысле слова: они являются частями экосистем, которые сами могут быть виртуальными, как интернет. 


\section{Plüïškarud, tamagotchi, transgeensed hiired: tehisloomade semiootiline tüpoloogia}

Väljend "tehisloom" tähistab vägagi erinevaid objekte plüüškarudest kuni geenitehnoloogia saavutusteni. Artiklis esitatakse kõigepealt "tehislooma" mõiste peamised tõlgendused, mis on aluseks edasisele arutlusele, ja vaadeldakse nende omavahelisi süstemaatilisi seoseid. Seejärel keskendutakse tehisloomadele mängu kontekstis. Materiaalsete mänguasjade arengu tagab robotroonika, mis varustab mänguasjad kunstlike tajuorganite, jäsemete ja kognitiivsete võimetega, võimaldades neil tegutseda reaalmaailmas. Teine arenguliin, mis on tihedalt seotud tehiselu uurimustega, loob virtuaalseid olendeid, mis "elavad" arvutiekraanil. Need kaks varianti erinevad eelkõige vastuvõtu modaalsuste poolest: virtuaalseid olendeid võib näha ja kuulda, aga materiaalseid mänguasju võib ka puudutada/kompida. Seetõttu osutub oluliseks puutetundlikkuse simulatsioon. Pakutava tüpoloogia täielikkuse huvides visandatakse kaks järgmist uurimisvaldkonda: tehisloomad väljaspool mängu ja "täisverelised tehisloomad" - elusad, kuid inimese poolt kujundatud ja loodud. Tehisloomade uurimine kuulub ökosemiootika valdkonda selle laias tähenduses, kuna nad on osa ökosüsteemidest, mis võivad ise olla ka virtuaalsed (nagu internet). 